\title{
Sezary Cell Count
}

National Cancer Institute

\section{Source}

National Cancer Institute. Sezary Cell Count. NCI Thesaurus. Code C74625.

The determination of the number of Sezary cells present in a sample. 